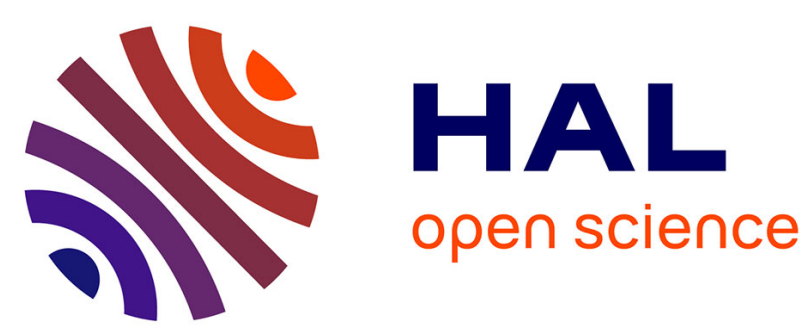

\title{
ON THE LONGITUDINAL CHARGE RESPONSE IN THE QUASI ELASTIC PEAK REGION
}

\author{
J. Jaenicke, P. Schuck, U. Stroth, R. Hasse
}

\section{To cite this version:}

J. Jaenicke, P. Schuck, U. Stroth, R. Hasse. ON THE LONGITUDINAL CHARGE RESPONSE IN THE QUASI ELASTIC PEAK REGION. International Workshop on Semiclassical and Phase Space Approaches to the Dynamics of the Nucleus, 1987, Aussois, France. pp.C2-71-C2-73, 10.1051/jphyscol:1987211 . jpa-00226476

\section{HAL Id: jpa-00226476 https://hal.science/jpa-00226476}

Submitted on 1 Jan 1987

HAL is a multi-disciplinary open access archive for the deposit and dissemination of scientific research documents, whether they are published or not. The documents may come from teaching and research institutions in France or abroad, or from public or private research centers.
L'archive ouverte pluridisciplinaire HAL, est destinée au dépôt et à la diffusion de documents scientifiques de niveau recherche, publiés ou non, émanant des établissements d'enseignement et de recherche français ou étrangers, des laboratoires publics ou privés. 


\title{
ON THE LONGITUDINAL CHARGE RESPONSE IN THE QUASI ELASTIC PEAK REgION
}

\author{
J. JAENICKE, P. SCHUCK, U. STROTH* and R.W. HASSE* * \\ Institut des Sciences Nucleaires, 53, Avenue des Martyrs, \\ F-38026 Grenoble Cedex, France \\ " Max Planck Institut für Plasmaphysik, D-8046 Garching, F.R.G. \\ * GSI, Postfach 110541, D-6100 Darmstadt 11, F.R.G.
}

\begin{abstract}
Résumé Nous généralisons notre théorie pour la fonction de réponse dans la région du pic quasi élastique au cas $N \neq Z$ et $l$ 'appliquons pour expliquer les mesures récentes de $\left(e, e^{\prime}\right)$ sur $238 \mathrm{U}$. Il y a persistance du problème de la charge manquante.
\end{abstract}

Abstract We generalise our theory for the linear response function in the quasi elastic peak region to the case $N \neq Z$ and apply it to the recently measured $e, e$ ' cross-section of $238 \mathrm{y}$. We find that the problem of the missing charge persists.

We have recently formulated and applied a semi-classical theory for the linear response to inelastic electron scattering on nuclei in the quasi elastic peak region [1] . We used the fully antisymetrised Gogny force which should be valid for momentum transfers $\mathrm{q} \leqslant 1.6 \mathrm{fm}^{-1}$ in the longitudinal charge channel. With no adjustable parameters we find quite satisfactory results over a wide momentum range for ${ }^{12} \mathrm{C}$ (see Fig. 1).

For increasing mass number this agreement of theory and experiment dramatically deteriorates. We generalised our theory for the $\mathrm{N} \neq \mathrm{Z}$ case to account for the recent ${ }^{238} \mathrm{U}$ data. In Fig. 2 we show at $\mathrm{q}=1.52 \mathrm{fm}^{-1}$ the results for ${ }^{56} \mathrm{Fe}$ and ${ }^{238} \mathrm{U}$. We see a very strong overshooting of the theoretical result with respect to the experimental data. For ${ }^{238} \mathrm{U}$ even more so than for ${ }^{56} \mathrm{Fe}$. A strongly mass dependent effect must therefore be at operation which is not taken into account within RPA theory. Noble and Shakin [3] proposed a swelling of the nucleon in the nuclear matter which leads to a modification of the nucleon form factor. We here argue for another possibility which could be given by the inclusion of $2 \mathrm{p}-2 \mathrm{~h}$ states. Indeed the Uranium data [4] do not seem to drop to zero up to the energies measured 


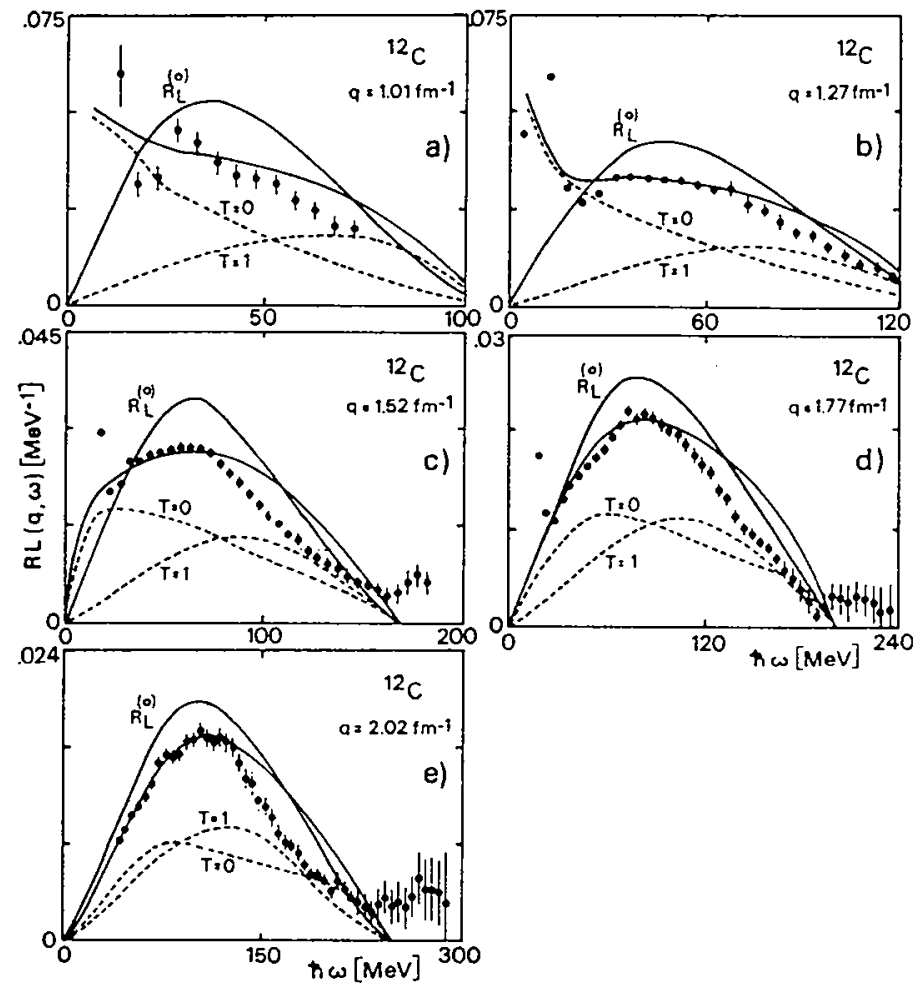

Fig. 1. The charge response for ${ }^{12} \mathrm{C}$ at five momentum transfers : the free response $\left(R_{L}{ }^{(0)}\right)$ and the interacting one (full lines) are compared to data from Barreau et a1 [2] . The decomposition of the interacting response into isoscalar and isovector contributions is given by the dashed lines.
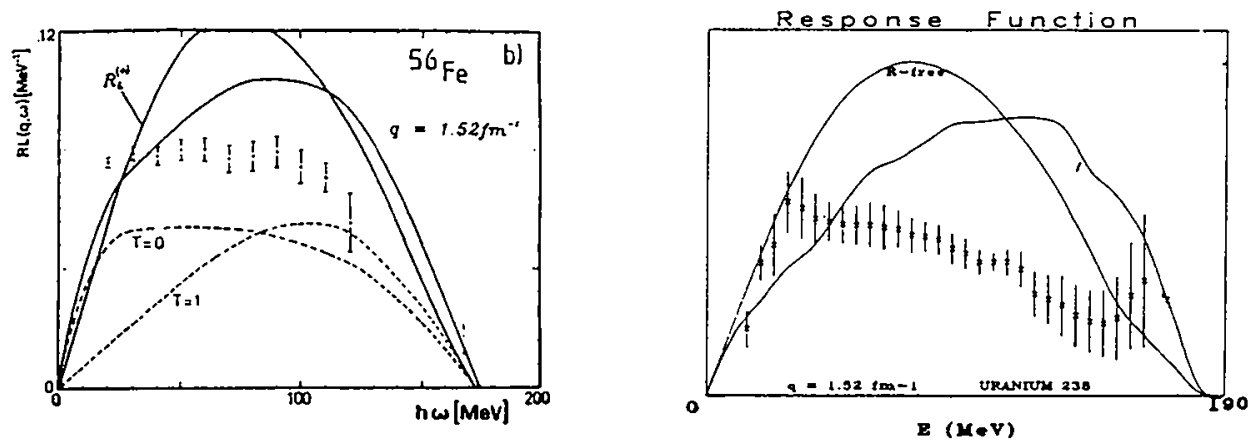

Fig. 2. Charge responses for ${ }^{56} \mathrm{Fe}$ and ${ }^{238} \mathrm{~J}$ at $\mathrm{q}=1.52 \mathrm{fm}^{-1}$. 
and ${ }^{56} \mathrm{Fe}$ as well as ${ }^{238} \mathrm{U}$ show a pronounced plateau structure at $\mathrm{q}=1.52 \mathrm{fm}^{-1}$ (this is the reason why we chose this value) which is absent for ${ }^{12} \mathrm{C}$. Within our theory this plateau could possibly be explained by the fact that the Gogny force in the isoscalar channel is attractive in the surface but repulsive in the bulk. The $2 \mathrm{p}-2 \mathrm{~h}$ states would then primarily smear out the isovector part of the response. That such a scenario can occur has recently been shown by Drozdz et al. [5]. On the other hand the density of $2 \mathrm{p}-2 \mathrm{~h}$ states is surely very strongly mass dependent as we show in Fig. 3.

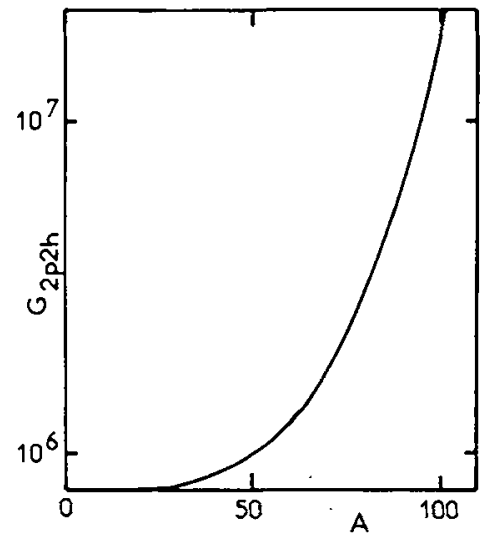

Fig. 3. $2 p-2 h$ level densities at fixed excitation energy as a function of mass number for a harmonic oscillator potential.

In conclusion we can say that the missing charge problem shows up very strongly also in the recently measured charge response of ${ }^{238} \mathrm{U}$. We can not account for the detailed shape of the cross section even with a modified nucleon form factor. We however give arguments that the inclusion of $2 \mathrm{p}-2 \mathrm{~h}$ states can play an important role in the quasielastic peak region.

ACKNOWLEDGEMENTS. We are grateful to G. Chanfrey for his help in generalising $1 \mathrm{i}-$ near response theory to the $N \neq Z$ case.

\section{REFERENCES}

1 U. STROTH, R.W. HASSE and P. SCHUCK, Nucl. Phys. A462 (1987) 45

2 P. BARREAU et al., Nuc1. Phys. A 402 (1983) 515 and note CEA N-2334, 1983

3 J. NOBLE, Phys. Rev. Lett. 46 (1981) 412;

C.M. SHAKIN, Nucl. Phys. A 446 (1985) $323 \mathrm{C}$

4 C.C. BLATCHLEY et al., Phys. Rev. C34 (1986) 1243

5 S. DROZDZ, V. KLEMT, J. SPETH and J. WAMBACH, Nucl. Phys. A 451 (1986) 11 